\section{Original article}

\title{
Cerebrospinal fluid ferritin in HIV infected patients with acute neurological episodes
}

\author{
F Deisenhammer, R F Miller, N S Brink, M J G Harrison, E J Thompson
}

\begin{abstract}
Objectives: To measure cerebrospinal fluid (CSF) ferritin in HIV infected patients with acute neurological episodes and to correlate the findings with the type and severity of neurological disease.

Methods: CSF ferritin and the ratio of CSF to serum albumin (QAlb) were prospectively measured in 27 consecutive HIV infected patients admitted to a specialist unit for investigation of acute neurological episodes; the results were compared with their clinical diagnoses.

Results: Ten patients had HIV associated dementia complex, six had cryptococcal meningitis, two had primary CNS lymphoma and nine had miscellaneous conditions including herpes simplex virus encephalitis, cytomegalovirus encephalitis, cerebral toxoplasmosis and mononeuritis multiplex. Overall, $16(59 \%)$ patients had raised CSF ferritin levels, ranging from 13.0 to $50 \cdot 2 \mu \mathrm{g} / \mathrm{l}$, (median $=16 \cdot 1 \mu \mathrm{g} / \mathrm{l}:$ normal range $=1 \cdot 0-12 \cdot 0 \mu \mathrm{g} / \mathrm{l})$. Thirteen of the 16 also had normal QAlb values, implying an intact CSF-blood barrier, and thus that local synthesis of ferritin had occurred. Elevated ferritin levels were not associated with particular neurological diagnoses. In those with HIV associated dementia complex there was no correlation between CSF ferritin levels and the severity of clinical cognitive deficit or the extent of magnetic resonance imaging abnormalities.
\end{abstract}

Conclusions: An elevated CSF ferritin level is a non-specific finding in HIV infected patients presenting with acute neurological episodes.

(Genitourin Med 1997;73:181-183)

Keywords: ferritin; AIDS; cerebrospinal fluid

\section{Introduction}

Ferritin is an iron storage protein which is present in virtually all body tissues. The highest concentrations of tissue ferritin are found in the liver and the reticuloendothelial system. ${ }^{1}$ Ferritin has also been detected extracellularly in serum, urine, saliva and cerebrospinal fluid (CSF). In normal individuals CSF ferritin concentrations are approximately $10 \%$ of those in serum. Elevated CSF ferritin levels have been reported in a variety of neurological disorders including subarachnoid haemorrhage, intraparenchymal cerebrovascular events such as haemorrhage and infarction, bacterial and fungal meningitis, viral encephalitis and cerebral vasculitis. ${ }^{2-6}$

It has been suggested that the major source of CSF ferritin is either from local synthesis in microglial cells, due to the presence of red cell iron or iron containing haem compounds, or alternatively that it reflects necrotic changes in the brain causing release of cellular iron, such as mitochondrial cytochromes. Thus CSF ferritin has been considered a marker of microglial activation. ${ }^{78}$ This study was undertaken to evaluate CSF ferritin levels in HIV infected patients presenting with acute neurological episodes. We sought to identify whether there was any correlation between elevated CSF ferritin levels and specific types of neurological disease in this patient group, or the severity of CNS changes.

\section{Methods}

We prospectively studied 27 consecutive HIV-
1 antibody positive patients admitted to a specialist HIV/AIDS in patient unit at University College London Hospitals for investigation of neurological episodes. The study was carried out within the guidelines of the Middlesex Hospital Clinical Investigations panel.

Twenty four patients were homosexual males (23 white, one Indian) and three were heterosexuals-two were females (one of whom was of African origin, the other white) and one was an African male. All were profoundly immunosuppressed with CD4 + lymphocyte counts ranging from 0 to $0.22 \times 10^{9} / 1$ (median count $\left.=0.05 \times 10^{9} / 1\right)$. Normal range $=0.35$ to $2.20 \times 10^{9} / 1$. Most patients had prior AIDS defining illnesses.

All patients were under the care of a specialist HIV physician (RFM) and were also seen by a neurologist (MJGH). They were investigated using a unit protocol. Following clinical assessment and magnetic resonance (MR) imaging of the brain lumbar puncture was carried out before institution of specific treatment. CSF protein and glucose concentrations were determined and the presence or absence of CSF pleocytosis was noted. CSF was stained histochemically and cultured for bacteria, mycobacteria and fungi and assayed for antibodies to Treponema pallidum and Toxoplasma gondii and for Cryptococcus neoformans antigen. An aliquot of CSF was analysed for the presence of cytomegalovirus (CMV), varicella zoster virus (VZV), herpes simplex virus type 1 (HSV-1) and Epstein-Barr virus (EBV) DNA by nested polymerase chain reaction (PCR) amplification, as previously described. ${ }^{9-12}$ 
Ferritin

A further aliquot of CSF was used to measure CSF ferritin using an ELISA assay as previously described. A value of $\geqslant 12 \mu \mathrm{g} / 1$ was considered to be elevated. ${ }^{7}$

\section{Albumin}

Measurement of albumin by electroimmunoassay was performed on CSF and serum obtained at the same time as lumbar puncture. ${ }^{7}$ The ratio of albumin in CSF and serum was expressed as the ratio QAlb calculated from (CSF albumin/serum albumin) $\times$ 1000. A value of $\geqslant 8$ was taken to reflect damage to the barrier between blood and brain. ${ }^{13}$

A diagnosis of HIV associated dementia complex was made on the basis of presentation with a subacute onset, over more than 1 month, of cognitive deficit, with decline in motivation, emotional control or change in social behaviour in the absence of clouding of consciousness, and the absence of demonstrable infection in the CSF by staining and bacterial, mycobacterial and fungal culture. ${ }^{14}$ In addition no evidence of CMV, HSV-1, VZV or EBV infection could be demonstrated using molecular amplification techniques. In those with HIV associated dementia complex we recorded the severity of the clinical cognitive deficit using the Memorial Sloan-Kettering criteria, ${ }^{15}$ and the MR imaging abnormalities of T-2 weighted diffuse white matter hyperintensity and cortical atrophy, as previously described. ${ }^{16}$

Cryptococcus neoformans meningitis was diagnosed by demonstration of the organism in CSF by staining and culture. Primary CNS lymphoma was diagnosed in two patients on the basis of typical MR appearances and demonstration of EBV DNA in CSF. Necropsy in one of these two patients and the patient with cerebral involvement with Hodgkin's disease also confirmed the diagnosis. The diagnosis of herpes simplex encephali- $\Omega$ tis was made at necropsy by the presence of extensive haemorrhagic necroses in the tempo-o ral lobes and by in situ hybridisation. The diagnosis of $\mathrm{CMV}$ mononeuritis multiplex was? made by the typical clinical presentation, iden-? tification of CMV DNA in CSF, and objective $\vec{F}$ response to anti-CMV therapy (ganciclovir).

Results amplification, ferritin and QAlb estimations

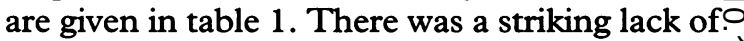
inflammatory response in the CSF of this $\vec{\omega}$ patient group; only two had a pleocytosis (due to lymphocytes in both patients). Fifteen had normal CSF total protein results (normal range $=0.05$ to $0.45 \mathrm{~g} / \mathrm{l}$ ) and only six had total ${ }^{\omega}$ protein values $>0.7 \mathrm{~g} / \mathrm{l}$; of these patients two $\stackrel{\infty}{\circ}$ had $C$ neoformans meningitis and two had pri-o mary CNS lymphoma.

Four patterns of abnormality of CSF ferritin and QAlb were observed. Thirteen patients, including six with HIV associated dementia $\vec{\bullet}$ complex, had elevated CSF ferritin levels and normal values of QAlb. Three patients hadi both elevated ferritin levels and an increase $\sum^{\circ}$ in QAlb. Ten had normal CSF ferritin and QAlb levels including four patients with HIV associated dementia complex. One patient $\stackrel{\odot}{\circ}$ with primary CNS lymphoma had an elevated $\vec{\circ}$

Table 1 Diagnosis, CSF findings and ferritin levels in HIV infected patients

\begin{tabular}{|c|c|c|c|c|c|}
\hline \multirow[b]{2}{*}{$\begin{array}{l}\text { Diagnosis/ } \\
\text { patient No }\end{array}$} & \multicolumn{4}{|c|}{ CSF findings } & \multirow[b]{2}{*}{$Q A l b$} \\
\hline & $\begin{array}{l}\text { Cells } \\
\left(/ \mathrm{mm}^{3}\right)\end{array}$ & $\begin{array}{l}\text { Protein } \\
(\mathrm{g} / \mathrm{l})\end{array}$ & $P C R$ & $\begin{array}{l}\text { Ferritin } \\
(\mu g / l)\end{array}$ & \\
\hline $\begin{array}{l}\text { HIV associated dementia complex } \\
1 \\
2 \\
3 \\
4 \\
5 \\
6 \\
7 \\
8 \\
9 \\
10\end{array}$ & $\begin{array}{l}0 \\
0 \\
0 \\
4 \\
0 \\
1 \\
1 \\
2 \\
0 \\
4\end{array}$ & $\begin{array}{l}0.56 \\
0.45 \\
0.24 \\
0.51 \\
0.13 \\
0.27 \\
0.47 \\
0.64 \\
0.19 \\
0.74\end{array}$ & $\begin{array}{l}- \\
- \\
- \\
- \\
- \\
- \\
- \\
- \\
- \\
-\end{array}$ & $\begin{array}{r}14.7 \\
7 \cdot 2 \\
15 \cdot 3 \\
32.0 \\
8.6 \\
50 \cdot 2 \\
3.6 \\
16.6 \\
21.9 \\
5.6\end{array}$ & $\begin{array}{l}3 \cdot 3 \\
6 \cdot 7 \\
4 \cdot 5 \\
7 \cdot 1 \\
2 \cdot 3 \\
4 \cdot 5 \\
4 \cdot 5 \\
5 \cdot 3 \\
3 \cdot 0 \\
6 \cdot 0\end{array}$ \\
\hline $\begin{array}{l}\text { Cryptococcal meningitis } \\
11^{\star} \\
12 \\
13 \\
14 \\
15 \\
16\end{array}$ & $\begin{array}{r}0 \\
65 \\
0 \\
4 \\
0 \\
1\end{array}$ & $\begin{array}{l}0 \cdot 81 \\
0 \cdot 24 \\
0 \cdot 37 \\
0 \cdot 31 \\
0 \cdot 77 \\
0 \cdot 35\end{array}$ & $\begin{array}{l}\text { CMV DNA+ } \\
- \\
- \\
- \\
-\end{array}$ & $\begin{array}{r}13.0 \\
30.4 \\
6.7 \\
13.4 \\
6.5 \\
15.5\end{array}$ & $\begin{array}{l}9 \cdot 5 \\
4 \cdot 0 \\
3 \cdot 4 \\
3 \cdot 3 \\
6 \cdot 5 \\
2 \cdot 8\end{array}$ \\
\hline $\begin{array}{l}\text { Cerebral lymphoma } \\
17 \\
18\end{array}$ & $\begin{array}{l}0 \\
0\end{array}$ & $\begin{array}{l}1.09 \\
0.87\end{array}$ & $\begin{array}{l}\text { EBV DNA+ } \\
\text { EBV DNA+ }\end{array}$ & $\begin{array}{l}11.9 \\
39.9\end{array}$ & $\begin{array}{l}8 \cdot 9 \\
4 \cdot 5\end{array}$ \\
\hline $\begin{array}{l}\text { Miscellaneous conditions } \\
19 \text { HSV encephalitis } \\
20 \text { CMV encephalitis/ } \\
\text { CMV retinitis } \\
21 \text { CMV mononeuritis } \\
\text { multiplex/retinitis } \\
22 \text { HIV mononeuritis multiplex } \\
23 \text { Vacuolar myelopathy } \\
24 \text { Cerebral toxoplasmosis } \\
25 \text { III N palsy } \\
26 \text { Cerebral Hodgkin's disease } \\
27 \text { Self limiting headache }\end{array}$ & $\begin{array}{r}0 \\
0 \\
0 \\
8 \\
28 \\
0 \\
2 \\
0 \\
0\end{array}$ & $\begin{array}{l}0.37 \\
0.87 \\
\\
0 \cdot 20 \\
0.32 \\
1.09 \\
0.29 \\
0.45 \\
0.29 \\
0.48\end{array}$ & $\begin{array}{l}- \\
\text { CMV DNA+ } \\
\text { CMV DNA+ } \\
- \\
- \\
- \\
\text { VZV DNA+ } \\
-\end{array}$ & $\begin{array}{r}13 \cdot 0 \\
15 \cdot 7 \\
\\
28 \cdot 6 \\
6 \cdot 8 \\
26.5 \\
6 \cdot 2 \\
14.9 \\
8 \cdot 2 \\
2 \cdot 8\end{array}$ & $\begin{array}{r}7 \cdot 1 \\
17 \cdot 4 \\
4 \cdot 7 \\
4 \cdot 1 \\
14 \cdot 8 \\
3 \cdot 0 \\
5 \cdot 2 \\
3 \cdot 8 \\
3 \cdot 4\end{array}$ \\
\hline
\end{tabular}

$\mathrm{CMV}=$ cytomegalovirus; $\mathrm{EBV}=$ Epstein-Barr virus; $\mathrm{VZV}=$ varicella zoster virus; $\mathrm{HSV}=$ herpes simplex virus

^Patient also had CMV retinitis; - = negative. 
Table 2 Severity of dementia, MR imaging abnormalities and CSF ferritin levels in 10 patients with HIV associated dementia complex

\begin{tabular}{rllll}
\hline & & \multicolumn{2}{l}{ MRI imaging abnormalityt } & \\
\cline { 4 - 5 } Patient No & Severity of dementia * & Atrophy & $\begin{array}{l}\text { Diffuse white matter } \\
\text { signal abnormalities }\end{array}$ & $\begin{array}{l}\text { CSF ferritin } \\
(\mu g / l)\end{array}$ \\
\hline 1 & Severe & Nil & Severe & $14 \cdot 7$ \\
2 & Mild & Moderate & Nil & $7 \cdot 2$ \\
3 & Moderate & Mild & Mild & $15 \cdot 3$ \\
4 & Mild & Moderate & Mild & $32 \cdot 0$ \\
5 & Mild & Moderate & Nil & $8 \cdot 6$ \\
6 & Moderate & Moderate & Mild & $50 \cdot 2$ \\
7 & Moderate & Mild & Mild & 3.6 \\
8 & Moderate & Mild & Nil & 16.6 \\
9 & Moderate & Severe & Severe & 21.9 \\
10 & Mild & Nil & Mild & $5 \cdot 6$ \\
\hline
\end{tabular}

${ }^{\star}$ Memorial Sloan-Ketting criteria (see Price and Brew) ${ }^{15}$ tPaley et al. ${ }^{16}$ and normal QAlb ratios: over half had normal total protein levels. It was in this context that we observed elevations of CSF ferritin. Clearly local synthesis of ferritin rather than ferritin derived from plasma is the explanation for the finding of elevated CSF ferritin levels. ${ }^{7}$ Even in those patients with elevated CSF ferritin the levels observed are somewhat lower than those previously reported in immune competent patients with neurological disease, ${ }^{27}$ suggesting that although microglia are activated by $\mathrm{HIV}^{17}$ their ability to synthesise ferritin is attenuated.

In conclusion these data show that an elevated CSF ferritin level is a non-specific finding in HIV infected patients presenting with acute neurological episodes, indicating that microglial activation is common in diverse clinical situations. Although elevated CSF ferritin levels were observed in some patients with conditions associated with cerebral necrosis the finding does not delineate the underlying pathology.

We thank Jane Rutherford for typing the manuscript.

1 Worwood M, Ahearne W, Dawkins S, Jacobs A. The characteristics of ferritin from human tissues, serum and blood cells. Clin Sci Med 1975;48:441-51.

2 Campbell DR, Skikne BS, Cook JD. Cerebrospinal fluid ferritin levels in screening for meningism. Arch Neurol 1986;43:1257-60.

3 Hällgren R, Terent $A$, Wide L, Bergström K, Birgegård G Cerebrospinal fluid ferritin in patients with cerebral infarction or bleeding. Acta Neurol Scand 1980;61: 384-92.

4 Sindic CJM, Collet-Cassart D, Cambiaso CL, Masson PL, Laterre EC. The clinical relevance of ferritin concentration in the cerebrospinal fluid. $f$ Neurol Neurosurg Psychiatry 1981;44:329-33.

5 Wick M, Fink W, Pfister P, Einhäupl K, Huber M, FatehMoghadam A. Ferritin in cerebrospinal fluid, differentiation between central nervous system haemorrhage and traumatic spinal puncture. $\mathcal{F}$ Clin Pathol 1988;41:809.

6 Zappone E, Bellotti V, Cazzola M, Ceroni M, Meloni F, Pedrazzdi $\mathrm{P}$, et al. Cerebrospinal fluid ferritin in human disease. Haematologica 1986;71:103-7.

7 Keir G, Tasdemir N, Thompson EJ. Cerebrospinal fluid ferritin in brain necrosis: evidence for local synthesis. Clin ferritin in brain necrosis: evide

8 Koeppen AH, Borke RC, Dearborn RE, Hurwitz CG. Ferritin as a marker for normal and pathological microglia. F Neurochem 1991;57 Suppl:118C.

9 Aurelius E, Johansson B, Sköldenberg D, Forsgren M Encephalitis in immunocompetent patients due to herpes simplex virus type 1 or 2 as determined by type-specific polymerase chain reaction and antibody assays of cerebrospinal fluid. $₹$ Med Virol 1993;39:179-86.

10 Fox JD, Brink NS, Zuckerman MA, Neild P, Gazzard BG, Tedder RS, et al. Detection of herpesvirus DNA by polymerase chain reaction in cerebrospinal fluid of human merase chain reaction in cerebrospinal fluid of human immunodeficiency virus-infected persons with neurologic disease: a prospect

11 Grant AD, Fox JD, Brink NS, Miller RF. Detection of varicella-zoster virus DNA using the polymerase chain reaction in an immunocompromised patient with transverse myelitis secondary to herpes zoster. Genitourin Med 1993;69:273-5

12 Mitchell SM, Fox JD, Tedder RS, Gazzard BG, Lightman $S$. Vitreous fluid sampling and viral genome detection for the diagnosis of viral retinitis in patients with AIDS. $F$ Med Virol 1994;43:336-40.

13 Reiber H, Felgenhauer K. Protein transfer at the blood CSF barrier and the quantification of the humoral immune response within the CNS. Clin Chim Acta 1987;16:319-28.

14 Janssen RS, Cornblath DR, Epstein LG, Foa RP McArthur JC, Price RW, et al. Nomenclature and research case definitions for neurological manifestations research case definitions for neurological manifestations
of human immunodeficiency virus-type 1 (HIV-1) infecof human immunodeficiency vir
tion. Neurology 1991;41:778-85.

tion. Neurology 1991;41:778-85.
15 Price RW, Brew BJ. The AIDS dementia complex. F Infect Dis 1988;158:1079-83.
Dice RW, Brew BJ. The Ant

16 Paley MNJ, Chong WK, Wilkinson ID, Shepherd JK, Clews AM, Sweeney BJ, et al. Cerebrospinal fluidintracranial volume ratio measurements in patients with HIV infection: CLASS image analysis technique Radiology 1994;190:879-86.

17 Puilliam L, Herndier BG, Tang NM, McGrath MS Human immunodeficiency virus-infected macrophages produce soluble factors that cause histological and neurochemical alterations in cultured human brains. $f$ Clin Invest 1991;87:503-12.
As noted in previous reports of HIV infected individuals undergoing investigation of neurological episodes ${ }^{10}$ there was a striking lack of inflammatory response in the CSF of our patients, the majority having no pleocytosis 